\title{
PERKEMBANGAN TEKNOLOGI SENJATA DAN PRINSIP PROPORSIONALITAS
}

\section{THE DEVELOPMENT OF WEAPON TECHNOLOGY AND PRINCIPLE of PROPORTIONALITY}

\author{
Erlies Septiana Nurbani \\ Faculty of Law, University of Mataram \\ Email : erlisseptiana.es@gmail.com \\ Naskah diterima : 10/03/2017; revisi : 25/03/2017; disetujui : 27/04/2017
}

\begin{abstract}
"Saat teknologi semakin canggih, tak ada yang namanya perang. Yang ada hanyalah bunuh diri dengan seketika. Anda menghancurkan lawan anda dalam satu detik, dan musuh andapun menghancurkan anda disaat bersamaan." (Anonim)
\end{abstract}

\begin{abstract}
This research seeks to answer the question of how the role of humanitarian law in regulate the development of weapons technology and its relationship with the principle of proportionality. This research is normative research which used statute approach and conceptual approach. War can not be separated from the technology development. Weapons technology development concomitant with the development of human civilization. The basic principle is man use weapons according to his time. Martin van Caravel identify the classification of weapon history into four phases, are age of tools, age of machines, age of system, and age of automation. This development definitely have correlation between the impact of development of weapons technology and human behaviour in war.

The more modern weapons systems used in war the more casualties and losses generated by the war. International humanitarian law purposes is to minimize the effects. The principle of proportionality is expected to be the direction for the parties to consider any attack not to be devastating, especially to the civilian although the written humanitarian law haven't accommodate the use of weapons as the result of war technology development, yet.
\end{abstract}

Keywords : Principle of Proportionality, War and Weapon

\section{Abstrak}

Tujuan penelitian ini adalah untuk menjawab pertanyaan bagaimana peran hukum humaniter dalam mengatur perkembangan teknologi senjata dan hubungannya dengan prinsip proporsional. Penelitian ini adalah penelitian normatif yang menggunakan pendekatan perundang-undangan dan pendekatan konseptual. Perang tidak dapat dipisahkan dengan perkembangan teknologi. Perkembangan teknologi senjata beriringan dengan perkembangan manusia. Pada prinsipnya, manusia menggunakan teknologi tergantung pada zamannya. Martin van Creveld mengidentifikasi pembabakan sejarah persenjataan ke dalam empat fase yaitu age of tools, age of machine, age of system, dan age of automation. Perkembangan ini sudah pasti memiliki korelasi antara dampak perkembangan teknologi dengan perilaku manusia dalam berperang. Semakin modern sistem persenjataan yang digunakan dalam perang semakin banyak korban dan kerugian yang dihasilkan oleh perang tersebut. Hukum humaniter internasional bertujuan untuk mengurangi dampak perang. Prinsip proporsionalitas diharapkan dapat menjadi panduan bagi para pihak bahwa serangan tidak menyengsarakan, khususnya bagi penduduk sipil, meskipun hukum humaniter tertulis belum mengakomodir penggunaan senjata yang dihasilkan oleh perkembangan teknologi perang terbaru.

Kata Kunci : Prinsip Proporsionalitas, Perang dan Senjata. 


\section{PENDAHULUAN}

Perang adalah sebuah kondisi yang sangat sulit untuk di hilangkan. Upaya untuk menghapus perang dari muka tidak mungkin berhasil untuk dilakukan. Namun yang dapat dilakukan adalah mengurangi penderitaan yang diakibatkan oleh perang dengan cara mengatur perang dengan sebuah aturan/hukum. Hukum yang dimaksud adalah hukum humaniter internasional, atau yang dahulu dikenal dengan hukum perang. Menurut Mochtar Kusumaatmadja, hukum humaniter internasional adalah bagian dari hukum internasional yang mengatur ketentuan-ketentuan perlindungan korban perang, berlainan dengan hukum perang yang mengatur perang itu sendiri dan segala sesuatu yang menyangkut cara melakukan perang itu sendiri.1

Black's Law Dictionary mendefinisikan hukum humaniter internasional adalah "law dealing with such matters as the use of weapons and other means of warfare, the treatment of war victims by the enemy and generally the direct impact of war on human life and liberty". ${ }^{2}$ Terjemahan bebasnya adalah "hukum perang adalah hukum yang berkaitan dengan penggunaan senjata pada saat perang, perlakuan terhadap korbankorban perang oleh musuh dan secara umum adalah mengenai dampak perang terhadap hidup dan kebebasan manusia".

Perserikatan Bangsa-Bangsa (PBB) telah menentukan bahwa perang adalah cara atau metode terakhir (last resort) yang dapat digunakan oleh para pihak untuk menyelesaikan sengketa diantara mereka sebagaimana yang tercantum dalam Pasal 2 ayat (4) Piagam PBB yang menyatakan bahwa "all members shall refrain in their international relations from the threat or

${ }^{1}$ Mochtar Kusumaatmadja dalam Arlina Permanasari, Aji Wibowo et all, Pengantar Hukum Humaniter Internasional, International Committee the of Red Cross, Jakarta, 1990, hlm. 5.

${ }^{2}$ HC Black, Blacks Law Dictionary, St Paul MinWest Publishing Co, USA, 1990 page 170. use of force against the territorial integrity or political independence of any state or any other manner inconsistent with the purpose of the United Nations".

Hukum perjanjian mengenai humaniter internasional yang ada saat ini merupakan produk hukum yang lahir sejak era perang dunia pertama dan perang dunia kedua, seperti Deklarasi St. Petersburg 1868, KonvensiDen Haag 1899 dan 1907, Konvensi Jenewa 1949 dan Protokol Tambahan 1977. Hal demikian menyebabkan hukum humaniter internasional belum dapat mencakup seluruh perkembangan teknologi yang lahir setelah Perang Dunia Kedua, khususnya perkembangan teknologi yang semakin pesat sejak Abad ke 20.

Dinamika perkembangan teknologi senjata beriringan dengan perkembangan peradaban manusia. Prinsip dasarnya adalah manusia menggunakan senjata dalam berperang sesuai dengan jamannya. Martin van Creveld mengidentifikasi pembabakan sejarah persenjataan ke dalam empat fase yaitu age of tools, age of machine, age of system, dan age of automation ${ }^{3}$. Perkembangan ini sudah pasti memiliki korelasi antara dampak perkembangan teknologi persenjataan itu sendiri dan perilaku manusia dalam berperang. Negara-negara besar seperti Amerika Serikat, Rusia dan Uni Eropa merupakan negara yang aktif dalam melaksanakan pengembangan teknologi di bidang persenjataan.

Teknologi perang yang berkembang saat ini seringkali dihadapkan pada persoalan bahwa teknologi yang digunakan seringkali menyebabkan penderitaan yang tidak perlu (unnecessary suffering), sebagaimana yang tercantum dalam prinsip proporsionalitas. Prinsip proporsionalitas bertujuan agar perang atau penggunaan senjata tidak menimbulkan korban, kerusakan dan

\footnotetext{
${ }^{3}$ Viotti and Kauppi dalam Irmawan Effendi, Cluster Bom dan Teori Just War : Perlindungan Sipil dalam Perang, Jurnal ISIP, Volume IX Nomor 1, Januari-Juni 2010, hlm 19.
} 
penderitaan yang berlebihan yang tidak berkaitan dengan tujuan-tujuan militer (the unnecessary suffering principles). Prinsip ini tercantum dalam Pasal 35 ayat (2) Protokol Tambahan I : "It is prohibited to employ weapons, projectiles and material and methods of warfare of a nature to cause superfluous injury or unnecessary suffering". Aturan dasar tersebut melarang penggunaan senjata, proyektil dan metode berperang yang menyebabkan luka yang berlebihan atau penderitaan yang tidak semestinya/ perlu.

Peran hukum humaniter sangat diperlukan dalam menghadapi perkembangan teknologi perang. Prinsip utama dalam penggunaan senjata sebagaimana diatur dalam hukum humaniter adalah bahwa selama terjadinya perang, nilainilai kemanusiaan harus tetap dihormati. Tujuannyabukanuntuk menolak hak negara untuk melakukan perang atau menggunakan kekuatan senjata untuk mempertahankan diri (self defence), melainkan untuk membatasi penggunaan senjata oleh suatu negara dalam menggunakan hak berperang tersebut untuk mencegah penderitaan dan kerusakan yang berlebihan dan yang tidak sesuai dengan tujuan militer.

Berdasarkan latar belakang di atas, untuk membatasi pembahasan dalam artikel ini maka ada beberapa hal yang perlu mendapat perhatian kita bersama :

a. Bagaimanakah perkembangan teknologi senjata saat ini?

b. Bagaimanakah hubungan antara prinsip proporsionalitas dan perkembangan teknologi senjata?

Penelitian ini merupakan penelitian normative dengan menggunakan pendekatan peraturan perundang-undangan (statute approach) dan pendekatan konseptual (conceptual approach). Statute approach adalah pendekatan yang beranjak dari peraturan perundang-undangan (dalam penelitian ini adalah konvensi atau perjanjian internasional) yang berkaitan dengan permasalahan yang di hadapi.

Conceptual approach adalah pendekatan yang beranjak dari pandangan-pandangan dan doktrin-doktrin yang berkembang di dalam khazanah hukum humaniter internasional. Dengan mempelajari pandanganpandangan dan doktrin-doktrin peneliti akan menemukan ide-ide yang melahirkan pengertian-pengertian, konsep-konsep dan asas-asas hukum yang relevan dengan isu yang di hadapi. Pemahaman atas pandangan-pandangan dan doktrin-doktrin tersebut merupakan sandaran bagi peneliti dalam membangun suatu argumentasi hukum guna memecahkan permasalahan yang dihadapi. Sumber data adalah data kepustakaan yang dianalisis dengan menggunakan teknik dokumentasi yaitu mengkaji berbagai referensi baik peraturan perundang-undangan maupun buku-buku literatur yang ada relevansinya dengan permasalahan yang diangkat.

Sebelum menjawab permasalahan dalam artikel ini, perlu untuk disampaikan beberapa teori-teori umum yang berkaitan dengan objek penelitian. Teori berfungsi sebagai alat prediction dan control bagi peneliti, sehingga peneliti memiliki skill untuk menggali data secara lengkap, mendalam serta melakukan konstruksi terhadap hasil penelitian. Oleh karena itu, penulis mengutip beberapa definisi dan teori

\section{Hukum Humaniter Internasional Pada Umumnya}

Masyarakat internasional sebenarnya telah sepakat bahwa perang sebagai usaha terakhir untuk menyelesaikan sengketa harus dihindari, sebagaimana yang tercantum dalam Pasal 2 ayat (4) Piagam PBB. Namun, sebagaimana fakta yang ditunjukkan selama ini, melarang perang merupakan suatu keniscayaan yang hanya dapat dilakukan adalah mengatur perang. 
Usaha masyarakat internasional untuk mengatur perang telah sama tuanya dengan perang itu sendiri. Sebagai contoh, filsuf asal China bernama Sun Tzu (298-238 SM) pernah mengeluarkan peraturan lengkap tentang peperangan. Demikian pula di zaman Hindia Kuno, ada ketentuan yang dituangkan dalam Laws of Manu. Kedua aturan tersebut selalu memasukkan pentingnya memperhatikan unsur kemanusiaan dalam perang. Walaupun telah ada aturan-aturan tersebut, tidak mengurangi kejamnya perang terhadap kehidupan manusia. ${ }^{4}$

Islam sendiri telah mengatur pelaksanaan peperangan5. Nabi Muhammad SAW menunjukkan bahwa selama peperangan perlindungan terhadap wanita, anak kecil dan orang tua adalah suatu kewajiban. Ajaran Islam tentang perang bisa dilihat dalam Al-Qur'an surat al-Baqarah ayat 190-191 dan 208, surat Al-Anfal ayat 39, surat At-Taubah ayat 5, dan surat al-Haj ayat 39 , yang memandang perang sebagai sarana pembelaan diri dan menghapuskan kemungkaran.

Perkembangan dalam hukum humaniter dimulai oleh sebuah buku yang berjudul Un Souvenirde Solverino yang dibuat oleh Henry Dunant. Buku tersebut menceritakan pengalaman penulisnya pada perang di Solferino (Italia Utara) pada tahun 1859. Dalam peperangan tersebut, banyak korban sipil yang memerlukan pertolongan. Buku itu mempengaruhi orang untuk berfikir pentingnya mengatur perlindungan bagi yang terluka saat perang.

Pengaruh dari buku ini meyakinkan masyarakat internasional untuk mendirikan

\footnotetext{
${ }^{4}$ Sri Setianingsih Suwardi, Serangan Israel Terhadap Lebanon Dikaitkan dengan Prinsip-Prinsip Hukum Humaniter, Indonesian Journal of International Law, Volume 4 Nomor 1 Oktober 2006, hlm.6

${ }^{5}$ Dalam perspektif Islam, perang tidak akan terjadi kecuali untuk menghentikan serangan musuh atau mempertahankan kebenaran permanen sesuai perjanjian yang dilanggar pihak musuh atau untuk pengamanan jalannya kebebasan beragama. Lebih lanjut lihat Zayyid bin Abdel Karim al Zayyid, Pengantar Hukum Humaniter Internasional dalam Islam, ICRC, 2008.
}

organisasi internasional yang netral, yang akan memberikan pertolongan bagi korban perang. Pada tahun 1863, berdirilah International Committee of the Red Cross (ICRC) dan tahun 1864 diadakan Konferensi Internasional di Jenewa, Swiss yang menghasilkan Convention on the Arneliration of the Condition of the Wounded in Armies in the Field. Konvensi ini dikenal dengan Konvensi Jenewa I. Konvensi Jenewa II yang ditandatangani pada tahun 1899 yang bernama Convention for the Armelioration of the Condition of the Wounded, Sick and Shipwrecked Members of Armed Forces at Sea. Pada tahun 1929, Konvensi Jenewa I diamandemen dan sekaligus dihasilkan Konvensi Jenewa III, Convention Relative to the Treatment of Prisoners of War. Pada tahun 1949, ketiga Konvensi itu diamandemen dan sekaligus dihasilkan Konvensi Jenewa IV, Convention to the Protective of Civilian Persons. ${ }^{6}$

Usaha masyarakat internasional untuk membuat rambu-rambu dalam peperangan kemudian dilanjutkan dengan Konferensi Perdamaian di Den Haag tahun 1899 dan 1907. Konferensi Perdamaian di Den Haag mengatur mengenai peperangan secara terperinci, baik peperangan di darat maupun peperangan di laut. Konferensi tersebut menghasilkan 13 konvensi, dari ketiga belas konvensi yang terpenting dalam kaitannya dengan hukum humaniter adalah Konvensi ke IV yaitu The Law and Customs of War on Land. Konvensi ke IV ini sering disebut dengan Hague Regulation (HR). HR ini memberikan batasan yang lebih tegas terhadap pemakaian alat dan metode berperang.

Aturan-aturan yang disebutkan di atas tadi adalah rambu-rambu yang disepakati oleh masyarakat internasional, agar pihak yang berperang memperhatikan dan menaati aturan-aturan yang telah disepakati. Sehingga, tujuan hukum perang itu dapat tercapai. Adapun tujuan dari hukum

\footnotetext{
${ }^{6}$ Ibid.
} 
humaniter menurut Mohammed Bedjaoui adalah tidak dimaksud kan untuk melarang perang tetapi adalah untuk memanusiakan perang. ${ }^{7}$ Adapun tujuan hukum humaniter menurut berbagai literatur yang ada, yaitu ${ }^{8}$ :

1. Memberikan perlindungan terhadap kombatan maupun penduduk sipil dari penderitaanyang tidak perlu (unnecessary suffering)

2. Menjamin hak asasi manusia yang sangat fundamental bagi mereka yang jatuh ke tangan musuh. Kombatan yang jatuh ke tangan musuh harus dilindungi dan dirawatsertaberhakdiperlakukansebagai tawanan perang.

3. Mencegah dilakukannya perang secara kejam dan tanpa batas.

Berdasarkan tujuannya, hukum humaniter mengatur dua hal pokok yaitu ${ }^{9}$ :

1. Memberikan alasan bahwa suatu perang dapat dijustifikasi yaitu bahwa perang adalah pilihan terakhir (the last resort), sebab atau alasan yang benar (just cause), didasarkan atas mandat politik (keputusan politik, political authority) yang demokratis, dan untuk tujuan yang benar (right intention);

2. Membatasi penggunaan kekuatan bersenjata dalam peperangan atas dasar prinsip proporsionalitas dan diskriminasi (proportionality dan discrimination). Dua hal pokok ini yang kemudian menjadi dasar prinsip pertanggungjawaban komando (command responsibility) yaitu bahwa seorang komandan mempunyai tanggung jawab untuk menegakkan hukum konflik bersenjata atau hukum perang atas dasar dua hal pokok tersebut di atas.

${ }^{7}$ Mohammad Bedjaoui, Modern Wars : Humanitarian Challenge A Report for the Independent Commission on International Humanitarian Issues, Zed Books, Ltd. London, 1986. Hlm. 2.

${ }^{8}$ Frederic de Mullinen, Handbook on the Law of War for Armed Forces, ICRC, Geneva, 1987, page 2.

${ }^{9}$ Ibid.

\section{Prinsip-Prinsip Hukum Humaniter In- ternasional}

Selain bersandar kepada aturan-aturan yang telah disepakati, perang yang dilakukan oleh negara baik yang bersifat internasional maupun non-internasional, juga harus memperhatikan prinsip-prinsip yang mendasar dari hukum humaniter internasional. Prinsip-prinsip Hukum Humaniter Internasional yang harus diperhatikan adalah :

1. Prinsip Kemanusiaan (Principle of $\mathrm{Hu}$ manity)

Prinsipkemanusiaaninimenentukan bahwa pihak yang berperang diwajibkan untuk berperilaku memperhatikan kemanusiaan, dimana mereka dilarang menggunakan kekerasan yang dapat menimbulkan penderitaan yang berlebihan. Individumempunyaihakuntukdihormati hidupnya, integritasnyabaikfisik maupun moral dan atribut yang melekat pada personalitasnya.

2. PrinsipPembedaan(DistinctionPrinciple)

Prinsip ini mengatakan bahwa pada waktu terjadi perang/konflik \bersenjata harus dilakukan pembedaan antara penduduk sipil ("civilian") di satu pihak dengan "combatant" atau antara objek sipil di satu pihak dengan objek militer di lain pihak. Berdasarkan prinsip ini, hanya kombatan dan objek militer yang boleh terlibat dalam perang dan dijadikan sasaran.

Prinsip pembedaan ini diatur dalam Konvensi Den Haag 1907 walaupun tidak secara eksplisit, namun secara implisit dapat kita temukan dalam Konvensi IV, khususnya dalam Hague Regulation, juga terdapat dalam Konvensi Jenewa, Pasal 13 (Konvensi I dan II), Pasal 4 (Konvensi III dan IV). Dalam Pasal 43 Protokol Tambahan 1977, istilah kombatan dinyatakan secara tegas, yaitu 
"angkatan perang terdiri dari semua angkatan bersenjata yang terorganisasi, kelompok (group) dan kesatuan (units) yang terorganisasi, yang berada di bawah pimpinan/komando yang bertanggung jawabkepadapihaktersebutataskelakuan dan tingkah laku mereka".

3. Prinsip Proporsionalitas (Proportionality Principle)

Prinsip proporsionalitas adalah "prinsipyangditerapkanuntukmembatasi kerusakan yang disebabkan oleh operasi militer dengan mensyaratkan bahwa akibat dari sarana dan metode berperang yang digunakan tidak boleh tidak proporsional (harus proporsional) dengan keuntungan militer yang diharapkan."

4. Prinsip Larangan Untuk Menyebabkan Penderitaan yang Tidak Seharusnya (Principle of Prohibition of Causing Unnecessary Suffering)

Prinsip ini sangat erat kaitannya dengan prinsip kemanusiaan. Pihak yang bersengketa dilarang menggunakan kekerasan yang dapat menyebabkan penderitaan yang berlebihan dan penderitaan yang tidak perlu. Masyarakat internasional memahami bahwa walaupun perang dapat dipakai sebagai cara untuk menyelesaikan sengketa, namun hak pihak yang bersengketa dalam menggunakan sarana dan metode perang dan tidak tak terbatas (is not unlimited).

Para pihak yang berperang memiliki keterbatasan dalam memilih alat dan metode berperang. Para pihak tidak dapat menggunakan senjata yang dapat menyebabkan penderitaan yang berlebihan (superfluos injury) atau penderitaanyang tidak perlu (unnecessary suffering).

5. Prinsip Kepentingan Militer (Military Neccesity Principle)
Prinsip kepentingan militer sebagaimana didefinisikan oleh ICRC, "military necessity expresses the idea that the use offorcemustbeprovided forandrecognized in law. Theforceused must take intoaccount the principle of proportionality. The main concernofhumanitarianlawistofind abalance between military necessity and humanitarian demands". ${ }^{10}$ Terjemahan bebasnya, "kepentingan militer menunjukkan ide bahwa penggunaan senjata harus disediakan dan diakui dalam hukum. Senjata yang digunakan harus mempertimbangkan prinsip proporsionalitas. Perhatian utama hukum humaniter adalah untuk menemukankeseimbanganantarakepentingan militer dan kemanusiaan". Prinsip ini menekankan bahwa para pihak dalam penggunaan kekuatan militer harus sah menurut hukum. Dalam menggunakan kekerasan, hal yang harus diperhitungkan adalah prinsip proporsionalitas dan keseimbangan antara kepentingan militer dan kemanusiaan.

\section{Sumber-sumber Hukum Humaniter In- ternasional}

Berbagai konvensi internasional yang mengatur mengenai hukum humaniter dapat dibedakan menjadi dua yaitu Hukum Den Haag dan Hukum Jenewa. Sebagaimana diketahui, bahwa Hukum Den Haag adalah hukum yang mengatur mengenai alat dan cara berperang sedangkan Hukum Jenewa mengatur mengenai perlindungan terhadap korban perang. Pembagian hukum humaniter ke dalam Hukum Den Haag dan Hukum Jenewa, dewasa ini tidak dapat dipisahkan secara rigid. Karena kenyataannya, suatu perjanjian tertentu sering kali berisi ketentuan-ketentuan yang merupakan Hukum Den Haag dan Hukum Jenewa.

\section{Hukum Den Haag}

Hukum Den Haag merupakan ketentuan hukum humaniter yang mengatur

\footnotetext{
${ }^{10}$ Ibid. Page 4.
} 
cara dan alatberperang. Hukum Den Haag bersumber dari hasil-hasil Konferensi Perdamaian Iyang diadakan pada tahun 1899 dan Konferensi Perdamaian II yang diadakan pada tahun 1907. Di samping itu ada beberapa instrumen hukum humaniter yang dibuat setelah dua konferensi perdamaian tersebut yang juga termasuk dalam kelompok Hukum Den Haag, misalnya Konvensi-konvensi tentang Senjata Konvensional tahun 1980.

a. Konvensi-Konvensi Den Haag 1899

Konvensi-konvensi Den Haag tahun 1899 merupakan hasil Konferensi Perdamaian I di Den Haag (18 Mei - 29 Juli 1899). Dalam konferensi perdamaian ini dihasilkan tiga konvensi dan tiga deklarasi. Adapun tiga konvensi yang dihasilkan adalah:

1) Konvensi I tentang Penyelesaian Damai Persengketaan Internasional.

2) Konvensi II tentang Hukum dan Kebiasaan Perang di Darat.

3) Konvensi III tentang Adaptasi Asas-asas Konvensi Jenewa Tanggal 22 Agustus 1864 tentang Hukum Perang di Laut

Sedangkan tiga deklarasi yang dihasilkan adalah :

1) Deklarasi tentang larangan penggunaan peluru-peluru dum-dum (peluru-peluru yang bungkusnya tidak sempurna menutup bagian dalam sehingga dapat pecah dan membesar dalam tubuh manusia).

2) Deklarasi tentang larangan peluncuran proyektil-proyektil dan bahan-bahan peledak dari balon.

3) Deklarasi tentang larangan penggunaan proyektil-proyektil yang menyebabkan gas-gas cekik dan beracun. b. Konvensi-Konvensi Den Haag Tahun 1907

Konvensi-Konvensi ini adalah merupakan hasil Konferensi Perdamaian Ke II yang merupakan kelanjutan dari Konferensi Perdamaian I Tahun 1899 di Den Haag. Konvensi-konvensi yang dihasilkanolehKonferensiPerdamaian II di Den Haag adalah sebagai berikut :

1) Konvensi I tentang Penyelesaian Damai Persengketaan Internasional;

2) Konvensi II tentang Pembatasan Kekerasan Senjata dalam Menuntut Pembayaran Hutang yang berasal dari Perjanjian Perdata;

3) Konvensi III tentang Cara Memulai Permusuhan;

4) Konvensi IV tentang Hukum dan Kebiasaan Perang di Darat yang dilengkapi dengan Regulasi (Peraturan) Den Haag;

5) Konvensi $\mathrm{V}$ tentang Hak dan Kewajiban Negara dan Orang-orang Netral dalam Perang di darat;

6) Konvensi VI tentang Status Kapal Dagang Musuh pada saat Permulaan Peperangan;

7) Konvensi VII tentang Pengubahan Kapal Dagang menjadi Kapal Perang;

8) Konvensi VIII tentang Penempatan Ranjau Otomatis di dalam laut;

9) Konvensi IX tentang Pemboman oleh Angkatan Laut di waktu Perang;

10)Konvensi $X$ tentang Adaptasi Asas-asas Konvensi Jenewa tentang perang di laut;

11) Konvensi XI tentang Pembatasan Tertentu terhadap Penggunaan Hak Penangkapan dalam Perang di Laut 
12) Konvensi XII tentang Pembentukan suatu Mahkamah Internasional tentang penyitaan contraband perang (barang selundupan untuk kepentingan perang);

13)Konvensi XIII tentang Hak dan Kewajiban Negara Netral dalam Perang di Laut.

2. Hukum Jenewa

Hukum Jenewa, yang mengatur mengenai perlindungan korban perang, terdiri atas beberapa perjanjian pokok yaitu empat Konvensi-konvensi Jenewa 1949, yang masing-masing adalah :

a. Konvensi Jenewa tahun 1949 tentang Perbaikan Keadaan Anggota Angkatan Perang Yang Luka dan Sakit di Medan Pertempuran Darat (Geneva Convention for the Amelioration of the Condition of the Wounded and Sick in Armed Force in the Field);

b. Konvensi Jenewa tahun 1949 tentang Perbaikan Keadaan Anggota Angkatan Perang Di Laut Yang Luka, Sakit dan Korban Karam (Geneva Convention for the Amelioration of the condition of the Wounded, Sick and Shipwrecked Members of Armed Forces at Sea);

c. Konvensi Jenewa tahun 1949 tentang Perlakuan Terhadap Tawanan Perang Geneva Convention relative to the Treatment of Prisoners of War);

d. Konvensi Jenewa tahun 1949 tentang Perlindungan Orang-orang Sipil di Waktu Perang (Geneva Convention relative to the Protection of Civilian Persons in Time of War).

Keempat Konvensi Jenewa tahun 1949 tersebut pada tahun 1977 dilengkapi dengan 2 Protokol Tambahan yakni :

a. Protokol Tambahan Pada Konvensi Jenewa tahun 1949 yang mengatur tentangPerlindunganKorbanSengketa
Bersenjata Internasional (Protocol Additional to the Geneva Convention of 12 August 1949, And Relating to the Protections of Victims of International Armed Conflict), selanjutnya disebut Protokol I; dan

b. Protokol Tambahan Pada Konvensikonvensi Jenewa tahun 1949 yang Mengatur tentang Perlindungan Korban Sengketa Bersenjata NonInternasional (Protocol Additional to the Geneva Convention of 12 August 1949, And Relating to the Protections of Victims of Non-International Armed Conflict) selanjutnya disebut Protokol II.

\section{PEMBAHASAN}

Perkembangan Teknologi Perang Saat Ini

Dalam sejarah, perang sudah dikenal bahkan sebelum adanya peradaban. Didalam bukunya, Lawrence mengatakan bahwa dalam penelitian arkeologi telah ditemukan berbagai bukti konflik bersenjata antar suku yang terjadi pada masa prehistoric, antara lain bukti fosil manusia pada masa itu yang mati terbunuh karena perang, senjatasenjata serta lukisan-lukisan batu di dalam gua yang menceritakan pertempuran. Bukti lain menunjukkan bahwa separuh kerangka dalam Nubian, sebuah kuburan prasejarah yang berusia 12.000 tahun, mereka tewas karena kekerasan yang menggunakan senjata. ${ }^{11}$

Senjata di dalam peperangan pada dasarnya dirancang untuk membunuh atau setidaknya melumpuhkan kekuatan potensial musuh. Kemampuan yang harus dimiliki tentunya memiliki kapabilitas melemahkan atau menghancurkan target serangan secara tepat dan efisien. ${ }^{12}$ Per-

\footnotetext{
11 www.wikipedia.co.id, War Before Civilization, diakses pada tanggal 8 Februari 2017

${ }^{12}$ Irmawan Effendi, Cluster Bom dan Teori Just War : Perlindungan Sipil dalam Perang, Jurnal ISIP, Volume
} 
kembangan senjata dan unsur pendukungnya tidak dapat dilepaskan dari perkembangan ilmu pengetahuan dan teknologi.

Hal ini senada dengan apa yang disampaikan oleh Terrence Taylor ${ }^{13}$ bahwa sebagai proposisi umum, ilmu pengetahuan dan teknologi diasosiasikan dengan produksi senjata, amunisi dan berbagai bentuk metode penyampaian tidak memprovokasi konflik bersenjata. Politik, historis dan ekonomi serta berbagai alasan lainnya dapat mengarah pada lahirnya konflik bersenjata, tapi tidak demikian senjata dan teknologi. Bagaimanapun, teknologi dan senjata dapat mempengaruhi atau bahkan menentukan jalannya konflik bersenjata, mempengaruhi kombatan dan penduduk sipil, berdampak pada lingkungan dan bahkan menentukan hasil dari peperangan. Senjata dan teknologi memiliki pengaruh yang sangat besar. ${ }^{14}$

Perkembangan baru menunjukkan bahwa dalam masalah-masalah internasional yang makin kompleks, penggunaan senjata tertentu atau cara berperang tertentu dianggap illegal atau bertentangan dengan prinsip-prinsip kemanusiaan atau paling tidak menjadi perdebatan, meskipun hal itu belum atau tidak diatur dalam ketentuan hukum internasional yang sudah ada tentang penggunaan senjata.15 Hal ini didasarkan atas argumen bahwa: "In any armed conflict, the right of the Parties to the conflict to choose methods or means of warfare is not unlimited" yang artinya bahwa dalam setiap sengketa bersenjata, hak para pihak yang terlibat dalam sengketa untuk memilih cara dan alat berperang adalah tidak tak terbatas (terbatas).

\footnotetext{
IX Nomor 1, Januari-Juni 2010, hlm 20.

13 Terence Taylor adalah anggota Directing Staff of the International Institute for Strategic Studies (IISS) dan President dan Direktur Eksekutif IISS Amerika Serikat dalam ICRC Review, Means of Warfare, Volume 87 Number 859 September 2005, hlm.419.

${ }^{14}$ Interview dilakukan oleh Toni Pfanner Editor in Chief of the International Review of the Red Cross pada 22 November 2005 dalam Ibid. Page 420.

${ }^{15}$ Irmawan Effendi, Op.Cit
}

Beberapa perkembangan senjata yang terjadi khususnya setelah perang dingin, yaitu $^{16}$ :

\section{Railgun}

Senjata yang memanfaatkan prinsip yang mengakselerasikan sasaran secara elektronik dengan interval 2 buah rel logam. Senjata ini mengubah energi listrik menjadi tekanan magnetis, dan melontarkan muatan terarah ke sasaran dengan tingkat kecepatan mendekati kecepatan suara. Tembakan dari senjata ini, memiliki kekuatan yang sanggup menembus berlembar-lembar lempeng baja nikel chrome molybdenum setebal $5 \mathrm{~cm}$ (bila tidak memiliki masalah pada kepadatan badan peluru).

\section{Sistem Senjata Sunyi DREAD}

Bayangkan pistol tanpa perlu kokang, tidak ada suara, tidak panas, mesiu, dan tidak ada penghentian atau kemacetan apapun. Sekarang bayangkan bahwa senjata ini bisa menembakkan proyektil kaliber 0,308 kaliber .50 logam secara akurat sampai dengan 8.000 fps (kaki per detik), menampilkan sebuah variabel tak terhingga dan mampu meletakkan bidang 360-derajatapi.Sisteminimemiliki kemampuan menembakkan 120 ribu peluru per menit.

\section{Aurora Excalibur}

Senjata ini merupakan pesawat tak berawak yang beroperasi dengan lepas landas dan mendarat secara vertikal. Pesawat ini dapat mencapai kecepatan $460 \mathrm{mph}$ (740 kmh) dan dapat membawa misil untuk ditembakkan. Pesawatinibisa melakukan semua hal itu melalui remote control. Excalibur berhasil diuji pada Juni 2009.

\section{Peluncur Granat XM-25.}

\footnotetext{
16 www.unikdunia.com, 10 Senjata Tercanggih di Dunia, Diakses pada tanggal 8 Februari 2017.
} 
Senjata ini mampu menembakkan 25 granat pada jarak apa pun, jarak dapat diatur dan diprogram pengguna. Senjata baru ini menggabungkan kemampuan menembak dan komputer.

\section{Cluster Bomb ${ }^{17}$}

Salah satu teknologi persenjataan yang digunakan di dalam perang, mendatangkan ancaman terhadap keamanan masyarakat sipil. Senjata jenis ini mampu mengeluarkan bom-bom kecil yang menyebar ke wilayah sasaran. Hal yang berbahaya dari senjata ini adalah kegagalan bom-bom kecil yang tidak meledak pada saatbersamaanjatuh di sasaran.Jeda waktu peluncuran dan kegagalan ledakan ini bisa mengenai masyarakat sipil yang beraktivitasdiwilayahtersebutsedangkan target serangan sudah bergerak.

Senjata yang dikembangkan seharusnya mengikuti konsep Jus in bello, bahwa perang harus dilaksanakan sesuai dengan hukum yang berlaku dalam perang, yang mencakupcaradilakukannyaperang (conduct of war) dan hukum yang mengatur mengenaiperlindungan orang-orangyang menjadi korban perang (Hukum Jenewa). Artinya efek kehancuran akibat perang bisadibatasidengan memproduksisenjata denganpresisitingkattinggi.Jikainisudah dipenuhi,makaakanjelastargetcombatant dan non combatant di dalam peperangan.

\section{Perlindungan terhadap Penduduk Sipil, Objek Sipil dan Benda-benda Cagar Bu- daya}

Pasal 48 Protokol Tambahan I $1977^{18}$ menentukan pihak-pihak dalam sengketa harus membedakan antara penduduk sipil dari kombatan dan antara obyek sipil

${ }^{17}$ Irmawan Effendi, Op.Cit.

18 Artikel 48 dalam Protokol Tambahan Konvensi Jenewa tertulis: In order to ensure respect for and protection of the civilian population and civilian objects, the Parties to the conflict shall at all times distinguish between the civilian population and combatants and between civilian objects and military objectives and accordingly shall direct their operations only against military objectives. dan sasaran militer, dan karenanya harus mengarahkan operasinya hanya terhadap sasaran militer saja. Ketentuan dalam Pasal 48 ini merupakan konkritisasi dari prinsip pembedaan (distinction principle). Prinsip pembedaan adalah prinsip yang membedakan antara kelompok yang dapat ikut serta secara langsung dalam pertempuran (kombatan) disatu pihak, dan kelompok yang tidak ikut serta dan harus dilindungi dalam pertempuran yaitu penduduk sipil. Pembedaan ini sangat diperlukan, dalam rangka melindungi korban-korban yang tidak perlu.

Pasal 51 ayat (2) menentukan bahwa penduduk sipil tidak boleh dijadikan sasaran dalam serangan dan Pasal 51 ayat (6) menentukan bahwa serangan terhadap penduduk sipil atau orang-orang sipil dengan cara tindakan pembalasan (reprisals) adalah dilarang Hal yang sama tertulis pada Artikel 52 (2) tentang General protection of civilian objects: Attacks shall be limited strictly to military objectives. In so far as objects are concerned, military objectives are limited to those objects which by their nature, location, purpose or use make an effective contribution to military action and whosetotal or partial destruction, capture or neutralization, in the circumstances ruling at the time, offers a definite military advantage.

Artikel 48 dan 52 ayat (2) sudah begitu jelas menguraikan tentang larangan bagi pihak yang terlibat dalam perang untuk menyerang fasilitas sipil. Penyerangan hanya ditujukan pada fasilitas militer yang berhubungan langsung dan mendukung aktivitas peperangan. Kemampuan dalam membedakan masyarakat sipil dan combatant harus dilaksanakan dengan cara menentukan sasaran yang memang betul-betul adalah fasilitas militer.

Protokol tambahan Konvensi Jenewa memberikan pembatasan terhadap senjata yang digunakan di dalam perang. Senjata 
yang digunakan tidaklah memberikan efek yang berlebihan dan penderitaan yang tidak diperlukan. Artikel 35 menjelaskan larangan penggunaan metode yang dapat memberikan efek luas dan juga kerusakan jangka panjang, "it is prohibited to employ methods or means of warfare which are intended, or may be expected, to cause widespread, long-term and severe damage to the natural environment."

Pasal 53 Protokol Tambahan I menentukan perlindungan bagi objek-objek budaya dan tempat pemujaan. Perlindungan terhadap objek-objek yang diperlukan bagi kelangsungan hidup penduduk sipil diatur dalam Pasal 54. Pihak yang bersengketa dilarang menimbulkan kelaparan sampai mati pada orang-orang sipil sebagai suatu cara berperang. Dilarang menyerang, menghancurkan, meniadakan atau menelantarkan objek-objek yang mutlak diperlukan bagi kelangsungan kehidupan penduduk sipil, seperti bahan makanan, menghancurkan daerah-daerah pertanian yang menghasilkan bahan makanan, hasil panen, ternak, instalasi air minum dan bangunan pengairan.

Perlindungan terhadap lingkungan alam diatur dalam Pasal 55. Pasal 56 menentukan perlindungan terhadap bangunanbangunan dan instalasi-instalasi vital, seperti bendungan, tanggul, pusat pembangkit tenaga listrik, tidak boleh dijadikan sasaran perang. Pasal 56 ayat (4) menentukan bahwa bangunan-bangunan, instalasi tersebut tidak boleh sebagai objek tindakan pembalasan (reprisals).

\section{Prinsip Proporsionalitas dan Perkem- bangan Teknologi Senjata}

Pengeboman Hiroshima dan Nagasaki pada Perang Dunia II oleh tentara sekutu dalam rangka menaklukan Jepang adalah salah satu kenyataan historis mengenai penggunaan teknologi senjata yang sangat bertentangan dengan prinsip proporsionalitas. Dilihat dari segi kepentingan militer, se- kutu berhasil dengan menyerahnya Jepang, namun terdapat ribuan penduduk sipil yang meninggal akibat pemboman tersebut. Akibat pemboman itu, dari 320.081 orang penduduk Kota Hiroshima, 118.661 terbunuh, 30.524 luka berat, 48.806 luka ringan dan 3.667 orang hilang. ${ }^{19}$ Merekapun menderita berbagai penyakit yang timbul karena adanya radiasi seperti pendarahan dalam, kanker dan leukimia. Tiga hari setelah itu, pemboman di Nagasaki juga mengakibatkan kerusakan yang hampir sama parahnya dengan apa yang terjadi di Hiroshima.20 Dan, ternyata, bertahun-tahun setelah pemboman tersebut, masih menyebabkan penderitaan yang berkepanjangan bagi penduduk Hiroshima dan Nagasaki. Banyaknya bayi cacat yang lahir karena radiasi, terganggunya fungsi reproduksi dan trauma yang ditinggalkan. ${ }^{21}$

Peristiwa Bom Atom Hiroshima dan Nagasaki merupakan fakta aktual dari pelanggaran prinsip proporsionalitas dalam hukum humaniter internasional. Prinsip proporsionalitas adalah salah satu prinsip fundamental dari Hukum Humaniter Internasional ${ }^{22}$, bersamaan dengan prinsip pembedaan dan kemanusiaan. Prinsip ini membatasi jumlah korban sipil dalam rangka menyerang objek militer yang sah. Walaupun dalam pelaksanaannya, prinsip ini adalah prinsip yang sangat sulit untuk ditaati oleh negara-negara yang sedang terlibat dalam konflik bersenjata.

${ }^{19}$ Survei Dewan Kota Hiroshima dalam Francoius Bugnion, The International Committe of the Red Cross and Nuclear Weapons : From Hiroshima to the Dawn of the 21st Century,ICRC Journal: Humanitarian Debate :Law, Policy and Action Means of Warfare,Volume 87 Number 859 September 2005. Hlm. 512.

${ }^{20}$ Ibid.

${ }^{21}$ Sri Setianingsih Suwardi, "Serangan Israel Terhadap Lebanon Dikaitkan dengan Prinsip-Prinsip Hukum Humaniter", Indonesian Journal of International Law, Volume 4 Nomor 1 Oktober 2006, hlm.12.

22 Prinsip Proporsionalitas merupakan bagian dari Hukum Kebiasaan Internasional yang mengikat semua negara. Dikodifikasinya prinsip ini dalam Protokol Tambahan I Konvensi Jenewa 1977 semakin memperteguh kekuatan mengikat prinsip tersebut. 
Penuntut pada International Criminal Tribunal for the Former Yugoslavia menyatakan bahwa "it is much easier to formulate the principle of proportionality in general terms than it is to apply it to a particular set of circumstances" ${ }^{\prime 2}$. Oleh karena itu, para pihak dalam peperangan harus dapat membandingkan secara objektif antara tujuan militer dan kemungkinan kerugian penduduk sipil dalam penggunaan suatu metode atau senjata tertentu. Kedua hal tersebut haruslah seimbang. Para pihak diwajibkan untuk dapat memperkirakan kerugian yang mungkin diakibatkan oleh metode atau senjata yang akan digunakan. Sehingga, sebuah serangan/senjata dianggap proporsional jika kemungkinan kerugian penduduk sipil tidak berlebihan dalam hubungannya dengan nilai yang dapat diperoleh dari serangan/senjata tersebut. ${ }^{24}$

Prinsip proporsionalitas diharapkan dapat menjadi arahan bagi para pihak yang terlibat dalam peperangan untuk mempertimbangkan setiap serangan pada pihak musuh untuk tidak menyengsarakan penduduk sipil. Usaha masyarakat internasional agar pihak yang berperang menaati prinsip proporsionalitas sebenarnya telah ditentukan dalam pasal 2 ayat (4) Piagam PBB. Walaupun dalam pasal tersebut tidak secara tegas menyebutkan prinsip proporsionalitas, namun pasal tersebut dengan tegas menyebutkan bahwa masyarakat internasional harus mengusahakan penyelesaian sengketa dengan damai dan menghindarkan penggunaan kekerasan dalam menyelesaikan sengketa diantara mereka.

\footnotetext{
${ }^{23}$ David Akerson, Applying Jus in Bello Proportionality in Drone Warfare, Oregon Review of International Law, Volume 16, 173, 2014, page 178.

${ }^{24}$ Selaras dengan Aturan 14 Daftar Aturan Kebiasaan Hukum Humaniter Internasional yang menyatakan bahwa, melancarkan penyerangan yang bisa diperkirakan bakal menimbulkan kerugian ikutan berupa korban tewas sipil, korban luka sipil, atau kerusakan objek sipil atau gabungan dari ketiga hal tersebut, yang merupakan hal yang berlebihan dibandingkan dengan keuntungan militer yang kongkrit dan langsung yang ingin dicapai, adalah dilarang.
}

Prinsip proporsionalitas ditujukan agar perang atau penggunaan senjata tidak menimbulkan korban, kerusakan dan penderitaan yang berlebihan yang tidak berkaitan dengan tujuan-tujuan militer. Sehingga, setiap pilihan dari penggunaan suatu senjata tertentu harus memenuhi keseimbangan antara kepentingan militer dan kerugian/kerusakan/kematian yang mungkin atau patut diduga dapat timbul dari penggunaan senjata tersebut. Faktanya, sangat sulit untuk menilai keseimbangan antara kepentingan militer dan kemungkinan kerugian yang ditimbulkan oleh suatu senjata baru.

Pada prinsipnya, larangan untuk menyebabkan penderitaan yang berlebihan atau luka-luka yang tidak perlu merupakan pencegahan dari penggunaan senjata yang bersifat membabi buta (indiscriminate attacks). Misalnya saja penggunaan senjata racun/gas beracun, senjata kimia, herbisida, dll. Penggunaan senjata semacam itu akan sangat menyulitkan untuk menilai keseimbangan antara tujuan militer dan objek serangan. Apakah senjata tersebut dapat efektif untuk melukai atau melumpuhkan military objects? Atau justru akan menimbulkan kerugian yang lebih besar bagi penduduk sipil, korban luka sipil dan kerusakan benda sipil. Oleh karena itu, sifat dari senjata yang membabi buta dilarang.

Larangan penggunaan senjata yang bersifat membabi buta selaras dengan Kebiasaan Hukum Humaniter Internasional sebagaimana diatur dalam Aturan 11 sampai dengan Aturan 13. Aturan 12 secara spesifik menyatakan yang dimaksud dengan serangan membabi buta, adalah25 :

a. Yang tidak diarahkan pada sebuah sasaran militer tertentu.

b. Yang menggunakan cara atau sarana pertempuran tertentu yang tidak dapat

${ }^{25}$ Daftar Aturan-aturan Hukum Humaniter Internasional Kebiasaan 
diarahkan kepada sebuah sasaran militer tertentu; atau

c. Yang menggunakan cara/sarana pertempuran yang dampaknya tidak dapat dibatasi sesuai dengan aturan Hukum Humaniter Internasional.

Sebagai contoh dari serangan yang membabi buta, antara lain ${ }^{26}$ :

a. Serangan yang dilakukan dengan pemboman, dengan cara atau alat apapun, yang memperlakukan sebagai suatu objek militer sejumlah objek militer yang berlainandanterpisah,yangterletakdalam satu kota, dusun atau wilayah, dimana terdapat pula konsentrasi penduduk sipil dan objek sipil.

b. Serangan yang dapat diharapkan akan menimbulkan korban jiwa pada penduduk sipil, luka-luka pada orang sipil, kerusakan pada objek sipil yang berlebihan, dibandingkan dengan hasil yang diharapkan.

Akibatnya, setiap serangan yang bersifat membabi buta bersifat mengenai sasaran militer maupun penduduk sipil atau objek sipil dalam peperangan. Sehingga, serangan membabi buta, baik dari aspek persenjataan maupun metode peperangan, adalah dilarang.

Prinsip proporsionalitas sangat berkaitan dengan prinsip kepentingan militer (military neccesity). Dalam menggunakan kekerasan, hal yang harus diperhitungkan adalah prinsip proporsionalitas yaitu keseimbangan antara kepentingan militer dan kepentingan kemanusiaan. Apakah metode atau persenjataan yang telah dipilih proporsional dengan kerugian yang mungkin diakibatkan olehnya. Sehingga, kemungkinan tersebut telah diperhitungkan sebelumnya, termasuk penggunaan metode dan senjata alternatif yang bisa diambil oleh anggota angkatan bersenjata jika dalam pelaksanaannya akan menimbulkan kerugian yang lebih besar, khususnya kerugian di pihak penduduk dan objek sipil.

Penggunaan prinsip kepentingan militer harus melalui lima tahap dan kelima tahap tersebut bersifat kumulatif, artinya kelima tahapan tersebut harus dipenuhi. Kelima tahapan tersebut adalah ${ }^{27}$ :

1. Tindakan Yang Dilakukan Tidak Melanggar Larangan Mutlak Hukum Humaniter Internasional

Walaupun menurut hukum humaniter internasional pihak yang berperang untuk dapat mencapai tujuannyam dimungkinkan untuk mengadakan penyerangan terhadap objek yang mungkinmerugikanbagipenduduksipil,namun kepentingan militer tidak dapat sebagai dasar pembenar untuk pelanggaran terhadap hukum humaniter internasional.

Pihak berperang harus menaati apa yang ditentukan dalam Pasal 52 Protokol Tambahan I 1977 yang menentukan perlindungan bagi objek-objek sipil.

2. Benar-Benar Ada Keharusan Untuk Melakukan Tindakan Tersebut

Pihak yang berperang harus dapat membuktikan terdapat keadaan militer genting yang mengharuskan diambilnya tindakan pelanggaran tersebut. Keadaan genting tersebut bisa berupa ancaman terhadapkesatuannyaolehtentaramusuh, keperluan logistik dan lain-lain. Komandan harus dapat membuktikan keadaan genting itu terjadi sebelum tindakan serangan terhadap musuh dilakukan, bukan sesudahnya.

3. Tindakan Yang Dilakukan Adalah Paling Tepat Untuk Meraih Kepentingan Militer Yang Diharapkan

26 Haryomataram, Pengantar Hukum Humaniter, Rajagrafindo Persada, Jakarta, 2012, hlm 180. 
Tindakan yang dilakukan adalah tindakan yang memberikan sumbangan yang efektif bagi aksi militer untuk mencapai keuntungan militer yang pasti.

4. Akibat Dari Tindakan Tersebut Memenuhi Prinsip Proporsionalitas

Akibat tindakan militer yang merugikan kepentingan penduduk sipil haruslahdiperhitungkanapakahkerugian yang diderita oleh penduduk sipil tersebut telah memenuhi prinsip proporsionalitas. Bila tindakan militer tersebut memenuhi syarat prinsip proporsionaliras baru tindakan tersebut dapat dibenarkan.

5. Cara Yang Diambil Sudah Melalui Pertimbangan Segala Aspek Yang Terkait.

Dalam menyusun strategi penyerangan, komandan harus mempertimbangkan segala kepentingan yang terkait, terutama aspek kemanusiaan. Aspek perlindungan terhadap penduduk sipil yang kemungkinan terkena aspek buruk dari tindakan militer yang diambil, harus dipertimbangkan. Tindakan militer tersebutharus dapatmeminimalisir kerugian penduduk sipil.

Prinsip proporsionalitas telah diakomodir dalam Additional Protocol I Konvensi 1977, Pasal 35 ayat (2) Protokol Tambahan I : "It is prohibited to employ weapons, projectiles and material and methods of warfare of a nature to cause superfluous injury or unnecessary suffering". Bahwa, dilarang menggunakan senjata, proyektil, material dan metode berperang yang menimbulkan luka-luka yang berlebihan dan penderitaan yang tidak perlu. Serta selanjutnya dikatakan pula bahwa menggunakan alat atau cara berperang yang mengakibatkan atau dapat diperkirakan akan menyebabkan kerusakan luas-hebat-berjangka panjang terhadap lingkungan hidup, adalah dilarang.
Ketentuan-ketentuan yang diatur dalam Additional Protocol I 1977 merupakan tambahan dari Hague Regulations 1907. Hague Regulations 1907 sendiri merupakan penyempurnaan dari Konferensi Perdamaian I di Den Haag 1899, sehingga seluruh rangkaian proses konferensi tersebut dikenal dengan Hukum Denhag.

Prinsip pertama yang terdapat dalam Hukum Denhag berbunyi, "the rights of belligerents to adopt means of injuring the enemy is not unlimited". Ini berarti bahwa adacara-caratertentudanalat-alattertentu yang dilarang untuk digunakan. Prinsip selanjutnya, yang merupakan prinsip penting dalam Hukum Denhag dan dianggapdapatmemberikanperlindungan hukum terhadap negara yang menderita kerugian dalam peperangan serta dapat melindungi penduduk sipil secara efektif khususnya terhadap perkembangan teknologi senjata, adalah prinsip Martens Clause28. Martens Clause terdapat dalam preamble Konvensi Denhag, berbunyi :

"Until a more complete code of the laws of wars has been issued, the High Contracting parties deem it expedient to declare that, in cases not included in the Regulations adopt by them, the inhabitants and the belligerents remain under protection and the rule of the principles of the law of nations, as they result from the usages established among civilized peoples, from the laws of humanity and the dictates of the public consciences".

Terjemahan bebasnya :

Apabila hukum humaniter belum mengatur suatu ketentuan hukum mengenai masalah-masalah tertentu, maka ketentuan yang dipergunakan harus mengacu ke-

\footnotetext{
${ }^{28}$ Diambil dari nama Ketua Delegasi Rusia, Frederic de Martens pada Konferensi Perdamaian di Denhag 1899. Frederic de Martens merupakan professor hukum internasional.
} 
pada prinsip-prinsip hukum internasional yang terjadi dari kebiasaan yang terbentuk dari bangsa-bangsa yang beradab, dari hukum kemanusiaan serta dari hati nurani masyarakat.

Martens Clause merupakan klausula yang sangat penting, karena dengan mengacu kepada prinsip-prinsip hukum dan kebiasaan-kebiasaan internasional yang diakui oleh bangsa-bangsa yang beradab, maka pengaturan sengketa bersenjata tidak hanya berdasar pada hukum humaniter tertulis (dalam bentuk perjanjian internasional). Klausula ini menekankan pada prinsip-prinsip kemanusiaan dan hati nurani masyarakat dunia, khususnya dalam menghadapi dan mengatur perkembangan baru dari teknologi militer.

Martens Clause terdapat dalam Additional Protocol I 1977, Pasal 1 ayat (2), yang menyatakan bahwa, "in cases not covered by this protocol or by other international agreements, civilians and combatants remain under the protection and authority of the principles of international law derived from established custom, from the principle of humanity and from dictates of public conscience". Nampak bahwa Pasal 1 ayat (2) Additional Protocol I merupakan pengulangan preamble Konvensi Denhag sebelumnya. Sehingga, kewajiban untuk melindungi penduduk sipil dan kombatan tidak hanya menjadi bagian $\mathrm{Hu}$ kum Denhag tetapi juga Hukum Jenewa ${ }^{29}$. Dapat disimpulkan bahwa Martens Clause merupakan salah satu dari common articles yaitu ketentuan yang bersamaan, yaitu beberapa pasal dalam Konvensi (Konvensi Jenewa) yang dipadang penting dan mendasar sehingga perlu dicantumkan dalam

${ }^{29}$ Klausula ini terdapat dalam berbagai perjanjian internasional yang mengatur tentang konflik bersenjata dengan naskah yang sama. Misalnya, dalam Pembukaan Protokol II, Pembukaan Conventional Weapons Convention 1980. Klausula ini semakin nampak urgensinya jika dilihat dalam berbagai batang tubuh dalam bentuk pasal-pasal sebagaimana terdapat dalam Konvensi jenewa 1949 dan Protokol I (Konvensi I: Pasal 63, Konvensi II : Pasal 62, Konvensi III : Pasal 142, Konvensi IV : Pasal 158). setiap Konvensi, baik dalam nomor pasal yang sama atau dengan redaksi yang hampir sama.

Pada dasarnya, Martens Clause memiliki dua fungsi utama, yaitu : ${ }^{30}$

First, despite the considerable increase in the number of subjects covered by the law of armed conflicts, and despite the detail of its codification, it is not possible for any codification to complete at any given moment, thus the Martens clause prevent the assumption that anything which is not explicitly prohibited by the relevant treaties is therefore permitted. Secondly, it should be seen as a dynamic factor proclaiming the applicability of the principles mentioned regardless of subsequent developments of type of situation or technology.

Terjemahan bebasnya, adalah :

Pertama, meskipun peningkatan yang cukup besar dalam jumlah subjek yang tercakup dalam hukum konflik bersenjata, dan meskipun detail dari kodifikasi, tidak mungkin untuk setiap kodifikasi untuk menyelesaikan konflik pada saat tertentu, sehingga klausula Martens mencegah asumsi bahwa apa pun yang tidak secara eksplisit dilarang oleh perjanjian yang relevan akan diizinkan. Kedua, harus dilihat sebagai faktor dinamis bahwa penerapan prinsip-prinsip yang disebutkan terlepas dari perkembangan situasi atau teknologi.

Martens Clause merupakan dasar moral yang telah diadopsi sebagai hukum. Meskipun perkembangan situasi dan teknologi semakin maju, Martens Clause menjadi dasar pembatasan bagi penggunaan berbagai jenis senjata oleh negara-negara yang terlibat dalam konflik bersenjata. Hal ini senada dengan apa yang disampaikan oleh International Court of Justice dalam

\footnotetext{
${ }^{30}$ Robert Kold dan Richard Hyde, An Introduction to the International Law of Armed Conflict, Hart Publishing, Oxford Portland Oregon, 2008, page 62.
} 
Nuclear Weapons Advisory Opinion, bahwa "the court would likewise refer, in relation to these principle (of the LOAC), to the Martens Clause, which was first included in the Hague Convention II with respect to the Laws and Customs of War on Land of 1899 which has proved to be an effective means of addressing the rapid evolution of military technology". ${ }^{31}$ Martens Clause telah terbukti sebagai media yang efektif dalam membatasi penggunaan teknologi militer terbaru dalam peperangan.

Sehingga, meskipun perkembangan teknologi militer/senjata belum diatur seluruhnya dalam suatu kodifikasi perjanjian internasional di bidang hukum perang, para pihak berkewajiban untuk mematuhi prinsip-prinsip fundamental dalam hukum humaniter internasional, khususnya prinsip proporsionalitas. Prinsip proporsionalitas dapat dijadikan sebagai sandaran bagi para pihak dalam konflik bersenjata. Sehingga, perlindungan terhadap penduduk sipil, khususnya, tetap dapat dipaksakan berdasarkan prinsip proporsionalitas.

\section{SIMPULAN}

Berdasarkan pembahasan di atas, penulis dapat menarik beberapa kesimpulan dalam penelitian ini, antara lain :

1. Bahwa perkembangan teknologi senjata mengalami perkembangan pesat, khususnya setelah pernag dingin. Negara-negara maju dalam bidang teknologi berperan aktif dalam mengembangkan teknologi senjata. Senjata yang diciptakan bersifat efektif, efisien dan mampu melumpuhkan kekuatan potensial musuh. Faktanya, perkembangan teknologi senjata merupakan hal yang belum diatur dalam kodifikasi hukum humaniter internasional. Hukum bergerak di belakang dalam hal ini.

2. Prinsip proporsionalitas adalah salah satu prinsip yang mendasar dalam

${ }^{31}$ Ibid. Page 63. hukum humaniter internasional. Prinsip proporsionalitas adalah prinsip yang diterapkan untuk membatasi kerusakan yang disebabkan oleh operasi militer dengan mensyaratkan bahwa akibat dari sarana dan metode berperang yang digunakan tidak boleh tidak proporsional (harus proporsional) dengan keuntungan militeryangdiharapkan. Sehingga, prinsip inimenjadikendalipihakyangbersengketa dalam melakukan serangan terhadap pihak lawan, baik dari segi persenjataan (sarana) atau pun metode (cara) yang digunakan untuk melemahkan pihak lawan.

\section{DAFTAR PUSTAKA}

\section{Buku dan Jurnal}

Arlina Permanasari, Aji Wibowo et all, Pengantar Hukum Humaniter Internasional, International Committee the of Red Cross, Jakarta, 1990

David Akerson, Applying Jus in Bello Proportionality in Drone Warfare, Oregon Review of International Law, Volume 16, 173, 2014.

Frederic de Mullinen, Handbook on the Law of War for Armed Forces, ICRC, Geneva, 1987.

KGPH Haryomataram, Pengantar Hukum Humaniter, Rajagrafindo Persada, Jakarta, 2012.

Henry Campbell Black, Blacks Law Dictionary, St Paul MinWest Publishing Co, USA, 1990.

ICRC Journal : Humanitarian Debate :Law, Policy and Action Means of Warfare, Volume 87 Number 859 September 2005.

ICRC Review, Means of Warfare, Volume 87 Number 859 September 2005.

Irmawan Effendi, Cluster Bom dan Teori Just War : Perlindungan Sipil dalam Perang, Jurnal ISIP, Volume IX Nomor 1, Januari-Juni 2010. 
Mohammad Bedjaoui, Modern Wars : Humanitarian Challenge A Report for the Independent Commission on International Humanitarian Issues, Zed Books, Ltd. London, 1986.

Robert Kold dan Richard Hyde, An Introduction to the International Law of Armed Conflict, Hart Publishing, Oxford Portland Oregon, 2008.

Sri Setianingsih Suwardi, Serangan Israel Terhadap Lebanon Dikaitkan dengan Prinsip-Prinsip Hukum Humaniter, Indonesian Journal of International Law, Volume 4 Nomor 1 Oktober 2006.

Zayyid bin Abdel Karim al Zayyid, Pengantar Hukum Humaniter Internasional dalam Islam, ICRC, 2008.

\section{World Wide Web}

www.wikipedia.co.id, War Before Civilization, diakses pada tanggal 8 Februari 2017

www.unikdunia.com, 10 Senjata Tercanggih di Dunia, Diakses pada tanggal 8 Februari 2017. 